\title{
アナログ図化機の幾何学的で静的な試験法
}

\section{Geometrisch-statishe Tests fur Analog-Auswertgeräte}

\author{
G. ボルマン ヘールブルク
}

1966年 4 月に発足した作業グループ II -2 は，その 広い対象分野にまたがる「真测量図化機の標準試験 法」の開発をいくつかの部門に分けた。この論文で取 上げる「アナログ図化機の幾何学的一静力学的試験 法」もその1つの分野である。

1966〜9 年にかけて，ブルクハルト教授を座長とし て開かれた作業グループの 4 回の会議で幾何学的一静 力学的な検定方法についての議論が特に多かった。そ の際現在使わ玌ているいろいろな構造の図化機のそれ ぞれに個有の試験方法を開発することは完全に不可能 とは云えないまでも難かしいことはすぐ明かになっ た。しかし写真測量の実際では同じ等級のアナログ汹 化機は構造原理が異なっていても大体同じような目的 に使われている。従って罒化機の使用者に，その図化 機がある目的に通した性能を持っているかどうかの情 報を，その構造如何とは無関係に考える試験法が当然 要求されてしかるべきである。

作業グループ II - 2 の座長であるブルクハルト教授 の「標準的な試験法 [1]」の一般報告に栖準試験法 の目標設定についての作業グループの見解がだされて いる。

それによれば標準試験法の結果は図化機の性能や調 整の状態を考え，完全なものてくりかえせば同じ結果 の得られるものでなければならない。測定と計算は特 別の器具を使わずに指定されたふつうの方法で実施て き，またそのための結果や時間も使用者にとって負担 にならないものでなければならない。これらの試験法 は総合的なものであってもよく，必ずしも個々の䛊差 の原因を完全に解明できる必要はない。以上のように 要約された目標設定に対する必要条件は部分的にはIL に矛盾するので，作業グループは将来もっと実際経験 の統計資料が積重ねられるまでの過渡的な解決法とし て最小限の試験法の歓告しかできないとの見解に達し た。

アナログ図化機用の幾何学的一静力学的試験として は次のものがある

1. 単格子設定法

2. 格子モデル測定法

この検定の具体的な実施法は後述するが，これは垂
㨁麦真用のアナログ図化機のためのもので，三次元の 侳標値の測定または記録值できる測定装置が必要であ る。また格子モデル測定法は標高測定の目盛が正確な スケールを備えた眓化機にも適用することができる。

アフイン困化の原理による図化機は，ここでは考慮 外として拝く。

前提

幾何学的一静力学的な試験法は前提として図化機の 調整の状況を考えるものでなければならないが，これ はただ図化機が調整されるべきかどうかをきめるため だけのものである。従ってこの試験は直接に役立った り，図化機のメ一カーに特別の指示を与えるためのも のではないが，たとえば個々の格子測定值からは指標 のゼロ位置の誤差についての定量的な情報を得ること もできる。

いずれの場合にも検定する四化機は既に一度たとえ ば組立後現在の場所で調整されていると仮定する。

\section{補助道具}

幾何学的一静力学的な検定法にとって重要な補助道 具は精密な格子板（最大座標誤差 $2 \sim 4 \mu$ ）で，その 格子間隔は $10 \mathrm{~mm}, 20 \mathrm{~mm}$ または $25 \mathrm{~mm}$ であり,孔つ うは図化機の附属品となっている。

補正板は無収差写真を使わない作業状態で使われる 戌化機の場合には使うことが望ましい。

ふつうより高倍率の接眼鏡を使うことは差支えない し，作業グループは観湘誤差を小さくするためにこの 方法を推奖する。

測定結果の計算に電子計算機を使うのは有利であ る。しかし計算は公式により，卓上計算機や計算尺 （たとえば誤差の計算用）のような簡単な器具を使っ てもできるものでなければならない。

\section{1. 単格子測定法}

\section{$1 \cdot 2$ 概 論}

一定の個数の格子点の機械座標の単格子 測定によ り，検査する投射器（図化機カメラ）の作る中心投影 の精度がわかる。測定值（または測定值から 理論值 を引いた残差）を最小自乗法によって写真面上の理想 的な配置状態に変換し，次に格子板の座標誤差を引く 
と, 残存誤差から投影の誤差が分り, また大ていはそ の解釈もできる。

特に以下のような幾何学的な誤差の存在を推定する ことができる（勿論その原因まで，それぞれの場合に 求めたり，除去したりすることできない)。

\section{対称的誤差}

主点から一定距離の格子点までの長さを, 直交座標 の 1 軸または兩軸方向に沿って，いろいろな長さにつ いて測って求められる。

\section{アフィン誤差}

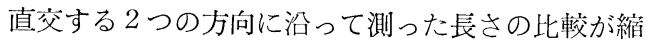
尺誤差を示す

\section{直交性の誤差}

\section{直線性の誤差}

\section{収差による誤差}

（主点を中心とした）半径方向の距離がその距離の 関数としての収差を持つ。この収差をきめるには多数 の格子点での測定が必要である。

収差の中にはまた，点対称でない。いわゆる歪曲収 差と切線方向の収差とがあり, 図化機ではメスマーク を隅の方に持って行ったときの系統的な偏心誤差とし て現われる。

格子板の各写真での単格子測定の際は 1 回の測定で なく 2 回の独立な測定を行なうべきで， 2 回目の測定 のときは 1 回目の測定のときとメスマークを近ずける 移動方向と測定方向を反対にすれば，次のような静力 学的な誤差が求められる。

バックラッシ（静力学的）

ある $1 つ の$ 格子点で測定でもメスマークを近ずけ る移動方向と測定方向がちがえば測定結果が異なる。 たとえばX軸の正方向と負方向に測った場合にX座標 值が異なる。原因：測定機構またはメスマークの誘導 機構のあそび（または締めすぎ）

\section{横ゆれ誤差}

バックラッシと同様であるが，今度は移動方向と直 角な方向の測定値が得られる場合である。すなわち X 軸の正方向に移動した場合と負方向に動かした場合と で $y$ 座標の值が異なる。原因：台車が運動方向から横 へずれるためで，たいていべアリングの調整不充分の 結果である。

理想的な格子点の配置状態への变換のために使われ るパラメーターの選び方により, 単格子測定からはさ らにいろいろな誤差, たと光ば投射器の内部および外 部の定位誤差が求められる。

変換式が投射器の回転の項を含んでいわば次の誤差 が分る

投射器の回転目盛の零点誤差
平行移動の場合も同様に求められる。従って次の誤 差が求まる。

\section{平行運動の誤差}

以下では格子板の平行移動とは 3 つの空間座標軸方 向と, 場合によっては機械座標系の零点位置の決定の ことである。もし単格子測定が 1 つの投影面だけでな く，2つ以上の投影距離の異なる投影面で行なわれて おれば，平行移動の誤差を写真空間内および外側の投 影空間内のものに分離することができる。

各投影面での単格子測定の変換が別々に行なわれて おり，図化機に㧈ける両方の測定值に差がないときは 平行運動の誤差は後続の計算過程で，2個含まれてい る平行運動のパラメーターから分離される。勿論たと えば 2 つ投影面に抢ける単格子測定の際に, 両方の 投影距離は近似的に測られ，両者の差はできるだけ正 確に測らなければならない。

そうすれば，画面距離の䛊差 $d c$ と $d z$ の䛊差（す なわち $b z$ の誤差）も求めることができる。同様のこ とが主点の位置䛊差 $a x_{p}, d y_{p}$ と鉛直点の誤差 $d x_{N}$ $d y_{N}$ （すなわち， bx，by の䛊差）についても成立つ

単格子測定結果の調整計算により, 座標の䛊差と単 位重量に対する中等䛊差が求まるほか, パラメーター の中等䛊差も求まる。さらにすべての䛊差に対して信 頼区間（一定の信頼係数, たとえば0.95）が考えられ る。

単位重量に対する中等䛊差の值は, あらかじめ個々 の座標の残差加計算しなくても, 容易に計算できる が,これによって図化機の状態が時間の経つに従って 悪化し, 調整やオーバーホールが必要であるかどうか を推定するに役立つ。

座標の䛊差をグラフ表示すれば, 何か系統的な変形 が存在するかどうかを概観することができ，またそれ によって 2 個の投射器で合成される正射投影の精度を 大体予想することができる。

たとえば両方の扱射器による単格子測定で同じ系統 䛊差が現われた場合は，その原因は投射器ではなく， 多分投影空間内の測定系にある筈であるという推定が 成り立つ。

最後にパラメーターとして得られた数值をその中等 䛊差の許容限界と比較することができる。許容限界よ り大きい場合はそれに対応する要素（たとえば目盛䛊 差）の調整が必要でその指示がなされるべきである。

以上のような一般的な議論から, 調整計算を行なっ た単格子測定は, 具体的な指示の得られる重要で有効 な方法であることがわかる。

何個の格子点を測るべきか，その点の配置をどうす るかは，計算能力や図化機の型式によってきまる。 
測定は比較的単時間に行なうことができるが，計算 量は点数が増えると急激に多くなる。電子計算機が使 えればこれは大した問題ではない。しかし，卓上計算 機によって計算ができるようにその条件を入れると， 格子点の数には制限があり, これはすでに 9 点が限界 と考えられる。

観測点の配置は, 写真面内の各部分に分散してえら び，実際の測定のときには順々に測定して行く。

単モデル用の図化機ては基線方向に非対称な配置が 良い。これに対し接続標定のできる空中三角測量用の 図化機では写真全面に対称的な点の配置が考虑される べきである。遠近 2 個の投影面で単格子測定を行なう 場合の, 投影距離は実作業での条件の他, 特に図化機 の運動範囲を考えてきめなければならない。これは図 化機の型により非常に異なるので各製作会社が各々の 型の図化機に対し, 測定点の有效ならび方を明示して おくように提案する。

測定される格子点の配列は計算に直接影響する。実 際の研究によれば，一般的な点の配列に使える計算公 式を作ることは常識的な経費では不可能である。従っ て卓上計算機による計算のために，少なくともすべて の係数をあらかじめ計算しておき，公式の中に常数と して与えておくことが必要である。この係数は点の位 置と画面距離の関数である。この際, 機械座標系のとり 方, 投射器の回転方向や, ゼ口位置のとり方, 測定の単 位, 正負の符号等が重要となって来るので,計算公式の 誘導はやはり図化機のメーカーに委せるべきである。

末尾の計算式は強制的なものてはない。これらは作 業グループまたは何処かのメーカーから提案されたも のてはなく, 卓上計算機での計算に使うための著者の 研究結果である。これらの計算式は単に問題点と計算 時間の 1 つの観点を示し, 単に今後の議論の基礎とな るにすぎない。

\section{2. 作業グループの勧告}

単モデル図化機の検定には 9 個の格子点を遠近 2 個 の投影面で, 2 回ずつ測定することを作業グループは 勧告する。測定值は平均をとり，それぞれの投影距 離ごとに別々に写真面上の長さに換算し, 座標䛊差: の計算のため理想的な格子点配置に座標変換する。こ の際 6 個の指定要素 ( 3 個の平行移動と 3 個の回転) をパラメーターとして使う。格子点の配列は別に指定 しないが，その際 1.1 節で述べた観点だけは留意され るべきである。測定は投射器をほぼ零状態（垂直状 態）に抢いて行なうべきである。補正板は使っても使 わなくてもよい。倍率の高い補助接眼鏡は使った方が よい。

\section{3. 実作業}

1.3 .1 座標系, 点の配列, および点の表示

以下の説明は第 1 回の座標系に基ずいている。これ は投影中心を原点としたものでX軸が基礎方向に（才 ペレーターから見て右方向が正), $y$ 軸が前方へ,才ぺ レーターから遠ざかる方向が正), $z$ 軸が下向きにな っている。投影空闒内の座標はすべて大交字で, 写真 空䦌内での座標は小文字で示してある。この座標系は 特定の図化機のものではない。これ以外の座標軸や回 転軸の配列の図化機の場合は座標記号を交換し, 符号 を変えて求められる。

点の配列と表示も第 1 网のとおりである。計算公式 は点の配列が軸に対称な場合と非対称な場合に分けて 求めた。

\subsection{2. 使用される符号について} 次のような符号がつかわれている。 $X, * Y^{*}=$ 機械単位 (ME) 或は $\mathrm{mm}$ 単位で表わした 投影空間に於ける理想的な座標值

$Z_{1}=\mathrm{mm}$ 単位で表わした遠面の投影距離

$Z_{2}=\mathrm{mm}$ 単位が表わした近面の投影距離

$X, Y=$ 機械単位 (NE) 或は $\mathrm{mm}$ 単位で表わした 投影空間に於ける実則坐標値 (インデック 又值と共に, 例えば $X_{H}$ か $X_{R}$. 測定が行 きか州りか，同様に $Y_{H} . Y_{R}$ )

$d X=X-X *$ 座標䛊差, $d Y$ も同様

$\Delta X=1 / 2\left(d X_{R}-d X_{H}\right)=$ 座標䛊差の半分, $\cdot Y$ も同様

$x, y=\mathrm{mm}$ 単位で表わした画面座標（格子点の座 標値）(格子板上の值)

$c=\mathrm{mm}$ 単位で表わしたカメラ定数(画面距離)

$k=$ メータ一単位てない $\mathrm{ME}$ から $\mu \mathrm{m}$ への換 算係数, その他は $K=10^{3}$

$d x, d y=\mu \mathrm{m}$ 単位で表わした画平面上での座標誤差

$P$ =重さ

$A=$ 䛊差平均行列式

$A^{T}=$ 転置した䛊差平均の行列式

$u \quad$ 媒介係数の分解ベクトル（誤差としての）

(䛊差ベクトル)

$b=$ 観測の分解ベクトル（画平面に換算された 座標䛊美）（観測誤差べクトル）

$e=-V=$ 残留座標䛊差べクトル（画面上の）

$Q$ ニコファクターマトリクス

$E=$ 単位行列

$e x, e y=\mu \mathrm{m}$ で表わした残留座標䛊差（画平面で）

$\left.\begin{array}{l}d_{x o} \\ d_{y o} \\ d_{c o}\end{array}\right\}=\begin{aligned} & \mu \mathrm{m} \text { で表わした並進運動（媒介係数 䛊差 } \\ & \text { として） }\end{aligned}$ 


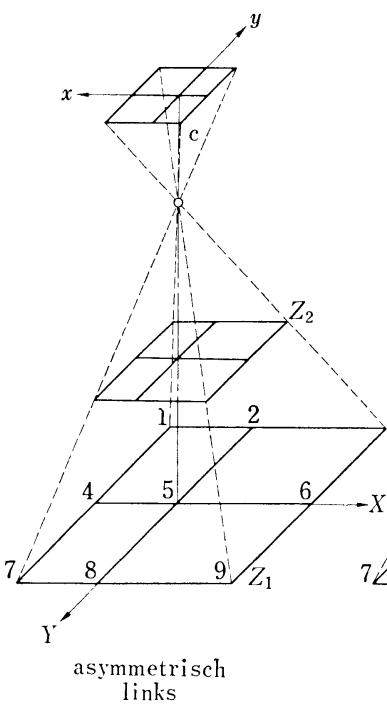

links

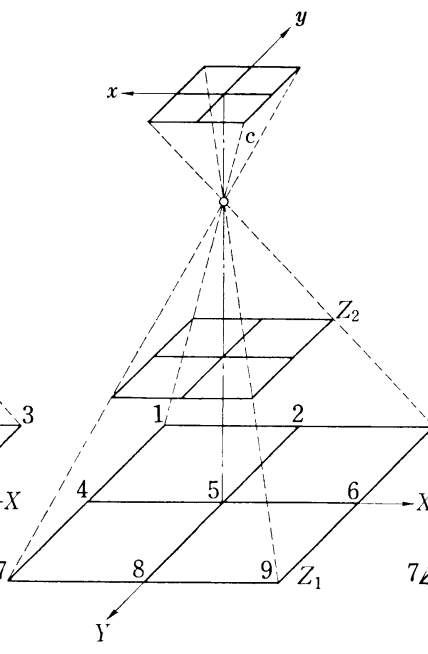

symmetrisch

図-1

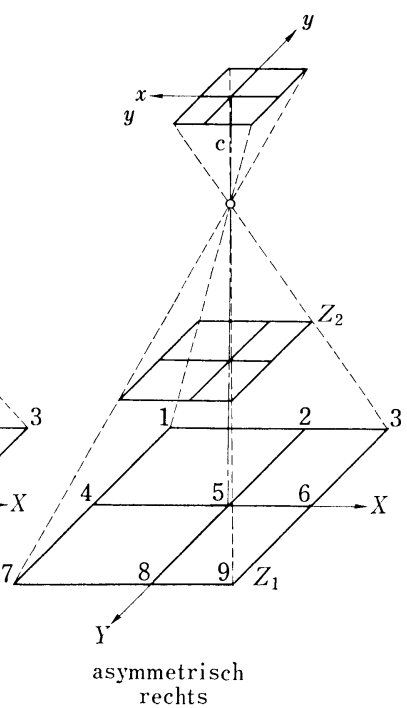

rechts

\section{3 .4 記 載}

各々の投影面で前進測定と後進測定で得られた座標 值は後の処理や計算のために出来るだけわかりやすい 形で記録する。フオームI はそのような整頓のこころ みである。機種, 点の配置, カメラ定数, 投影面の位 置, 基線の位置等をもとに計算さる機械座標の理想值 を第 2 欄に入れる。理想値を記録する場合，得られる 測定值の単位を用いる。第 3 , 第 4 欄は前進測定及び後 進測定で得られた座標を記録するためのものであり， 読取カウンターの最終間隔の目測值も含めて記録す る。第 5 , 第 6 欄は現想值と実測值の差て䛊差計算機 械座標系で)のために用いる。ここでは小数点以下だけ かき入れる。座標測定する場合 $\mu \mathrm{m}$ 単位でもよい。第 7 欄は（後進前進）の半分の值を人れる。この值は静 的な䛊差，バックラッシュを教える。第 7 欄の符号 は，例へば，バックラッシュの平均值を得るために差 の符号は（十）のままにしておき，加算の場合には， 逆に（一）にしなければならない。この符号は移動方 向によって決められる。第 8 欄は係数 $k_{c} / z_{1}$ や $k_{c} / z_{y}$ で写真面の大きさに換算した䛊差の平均值を入れる。 係数 $\kappa$ はメーター単位でない機械のときだけ 1 ではな い。第 9 欄は $\mu \mathrm{m}$ 単位で数值を記入する。これはフ ォーム 2 (2L, $2 R$ も含む) とフォーム 3 （3L, $3 R$ を 含む）への計算のために使われる。

\section{3 .5 計算式}

写真面上の大きさに直された座標䛊差を対応する理 想的な格子点の形状に変換するためには重量 1 の観測 值の平均のための行列を使った例の式が用いられる。 1.3 .1 章と 1.3 .2 章の表示法を考慮して普通のフォー 


$$
m d x_{p}= \pm \sqrt{z^{2} m^{2} d x_{o 1}+Z_{2}{ }^{2} m^{2} d x_{o 2}} /\left(Z_{1}-Z_{2}\right)
$$

$m d x_{N}= \pm \sqrt{m^{2} d x_{o 1}+m^{2} d x_{o 2}} \quad Z_{1} Z_{2} / c\left(Z_{1}-Z_{2}\right)$

$$
\left(m d y_{p} \pm m d y_{N}\right. \text { については四的に) }
$$

$m d c= \pm \sqrt{Z_{1}^{2} m^{2} d c_{o 1}+Z_{2}^{2} m^{2} d c_{o 2}} /\left(Z_{1}-Z_{2}\right)$

$m d z= \pm \sqrt{m^{2} d c_{o 1}+m^{2} d c_{c 2}} Z_{1} Z_{2} / c\left(Z_{1}-Z_{2}\right)$

次々と計算された媒介係数についての許容区間は

$12+12-2=22$ の自由度の場合信頼係数を 0.95 とし $\tau$

$$
\pm 2.07 m t
$$

このパラメーターの中等誤差は一般的に $\mathrm{mt}$ で表はさ れている。

1.3 .6 計算式

与えられている公式は電算機用のもので例えばIBM 360 型では約 1 分以内で計算出来る。又プログラミ ングも簡単で, 行列式計算でもほとんど今のサーブル チンで行うことが出来る。

卓上計算機ではこれはむつかしい，もし全ての残留 座標誤差を計算する必要があるならば 9 対の測定座 標からそれに対応した理想形への変換にはかなりの計 算費用が必要である。結局 2 つのプロシェェクター $2 つ$ の投影面に対する 4 つの平均計算を丸々行うことにな る。

画平面における $x$ 軸と $y$ 軸に対して対称的な格子
点配置の場合簡易化出来るのは正規方程式が独立な幾 つかの部分に分けられるからである。例えば文献 [ 3] にみられるように置換及び総括により計算は簡単にな る。ここでは画面座標軸が非対称的な点配置について は省咯する。

一般の 9 点配置と任意のカメラ定数に対する計算式 を展開することは実際には不可能である。唯一の実行 出来る方法として今迄与えられた, 点の配置とカメラ 定数に対してまえもって計算された係数をもった公式 が，用意されている。附録のフォーム案は行列方程式 (5) と（3b) にもとづいて作られたものである。前 者では, 座標残存誤差が, 後者では, 測定された座標 䛊差の函数としてのパラメータが用いられる。公式

(5) よりカメラ常数と 3 つの異なる点配置に対して 行列式 $\left(E-A Q A_{T}\right)$ が転置した形で示される。公式 $(3 b)$ からは行列式 $\left(Q A^{T}\right)$ の要素が示される。従っ て非常に重要な残留䛊差の計算は測定された投影面ご とに 18 の加算する操作で取り出す。これが要求され る限界内にあるならば卓上計算機で出来る。この計算 の長所は媒介係数を計算しないで残留誤差が得られる ことである。行列式（9）に打いて第 1 欄と第 2 欄 の要素が常に常数であるため $[e x]$ と同様 $[e y]$ も 零で，これは検算のときに使われる。媒介係数の計算 は測定される投影面每に6つの積和の操作によって後 で行はれる。

（堀江延韶訳） 